\title{
Coal mining in northeast India: an overview of environmental issues and treatment approaches
}

\author{
Mayuri Chabukdhara ${ }^{1}$ O. P. Singh ${ }^{2}$
}

Received: 22 October 2015/Revised: 28 February 2016/ Accepted: 28 March 2016/Published online: 25 May 2016

(C) The Author(s) 2016. This article is published with open access at Springerlink.com

\begin{abstract}
Northeast India has a good deposit of sub-bituminous tertiary coal. The northeast Indian coals have unusual physico-chemical characteristics such as high sulfur, volatile matter and vitrinite content, and low ash content. In addition, many environmental sensitive organic and mineral bound elements such as $\mathrm{Fe}, \mathrm{Mg}, \mathrm{Bi}, \mathrm{Al}, \mathrm{V}, \mathrm{Cu}, \mathrm{Cd}, \mathrm{Ni}, \mathrm{Pb}$, and $\mathrm{Mn}$ etc. remain enriched in these coals. Such characteristics are associated with more severe environmental impacts due to mining and its utilization in coal based industries. Environmental challenges include large scale landscape damage, soil erosion, loss of forest ecosystem and wildlife habitat, air, water and soil pollution. Several physical and chemical methods are reported in literature for the removal of mineral matter, total sulfur and different forms of sulfur from high sulfur coal in northeast India. This paper may help different researchers and stakeholders to understand current state of research in the field. Initiatives may be taken towards sustainable use of coal resources by adopting innovative clean technologies and by implementing effective control measures and regulatory policies.
\end{abstract}

Keywords Northeast India $\cdot$ Sub-bituminous coal $\cdot$ Environmental issues $\cdot$ Innovative technologies $\cdot$ Management and regulatory policies

\section{Introduction}

Coal is the most important and abundant fossil fuel in India. With increased population, growing economy and a quest for improved quality of life, energy demand in India is rising. Mining is not only fulfilling the increasing energy demand of industry, but also plays an important role in the economic development of the country (Chaulya and Chakraborty 1995). Power sector is the largest consumers of coal followed by iron, steel and cement segments in the

Mayuri Chabukdhara

mayuri_chabukdhara@yahoo.co.in

1 Department of Environmental Biology and Wildlife Sciences, Cotton College State University, Guwahati, Assam 781001, India

2 Department of Environmental Studies, North Eastern Hill University, Shillong, Meghalaya 793022, India last four decades (Fig. 1). Other smaller consumers include fertilizer, textile (including jute and jute products), paper and the brick industry. Coal mining and its utilization is associated with substantial environmental challenges as it creates significant and often irreversible impacts upon the terrestrial and aquatic environment.

Open cast or surface mining is dominant in India and it not only alters the nature of groundwater-surface water interactions but also contributes to major air pollutants to the atmosphere and results in dramatic changes in the landscape. Most coal mining districts in India have been declared as critically polluted areas (CPAs) by MoEF in 2009 (CSE 2012).

In northeast India, coal mining was initiated by Medlicott in 1869 and 1874 (Sarma 2005a, b). The Cenozoic coals in the northeast states of India with its unusual physico-chemical characteristics have been playing an important role in the Indian economy for the last few decades (Baruah 2009; Saikia et al. 2014a). Due to its unique properties and consequent environmental issues, 


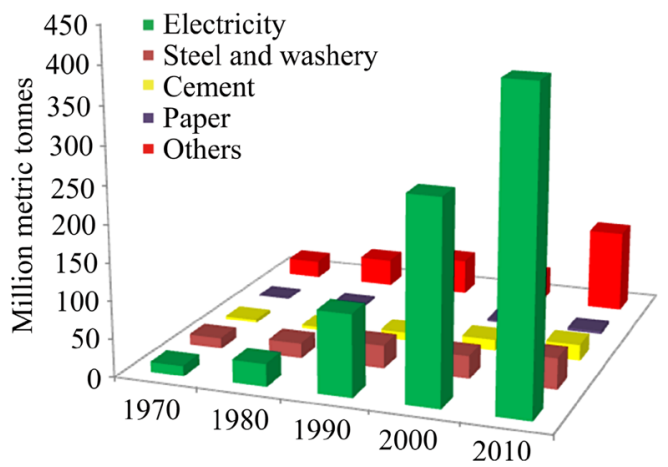

Fig. 1 Consumption of raw coal by different industries in India. Source: India Energy Book 2012

coals in northeast India draw special attention (Zamuda and Sharpe 2007; Saikia et al. 2014a).

The main objective of this paper is to summarize coal characteristics and associated environmental issues in northeast India. In addition, this paper also reviews the current state of research in the field of various treatment approaches to reduce environmental impacts of coal.

\section{Coal distribution and its characteristics in northeast India}

As on April 2014, India's inventory of coal resource was 300 Billion Tons (BT) comprising of: Proven-125 BT; Indicated-142 BT and Inferred-32 BT (Ministry of Coal 2014). Northeast India contributes 105 Million Tons (MT) of the Gondwana coal and 1492 MT of tertiary coal reserves. Meghalaya and Assam in northeast India contain $73 \%$ of the total tertiary coal reserves. Nagaland and Arunachal Pradesh contribute $21 \%$ and $6 \%$ of the total tertiary coal reserves, respectively. Coal inventory of northeast India is given in Table 1.

Sub-bituminous tertiary coal of northeast India was deposited under the influence of marine environment

Table 1 Northeast India's coal inventory of Gondwana and tertiary coal in million tones (Ministry of coal, India as on April 1, 2014)

\begin{tabular}{llrccl}
\hline Coalfield & State & Proved & Indicated & Inferred & Total \\
\hline \multirow{2}{*}{ Gondwana } & Assam & 0 & 4 & 0 & 4 \\
& Sikkim & 0 & 58 & 43 & 101 \\
& Total & 0 & 62 & 43 & 105 \\
\multirow{5}{*}{ Tertiary } & Arunachal Pradesh & 31 & 40 & 19 & 90 \\
& Assam & 465 & 43 & 3 & 511 \\
& Meghalaya & 89 & 17 & 471 & 577 \\
\multirow{6}{*}{ Total } & Nagaland & 9 & 0 & 307 & 316 \\
\hline
\end{tabular}

Source Ministry of coal (2014)
(Rajarathnam et al. 1996). These coals have high sulfur and low ash content, with high organic sulfur, due to the influence of marine sources during diagenesis (Chandra et al. 1983; Singh and Singh 2000; Ward et al. 2007; Widodo et al. 2010). Coal can be termed as low sulfur $(<1 \%$ sulfur content), medium sulfur $(1 \%-<3 \%$ sulfur content) and high sulfur coals ( $>3 \%$ sulfur content) based on their sulfur contents (Chou 2012). In addition to high sulfur content, northeastern coals have a high content of volatile matter and vitrinite contents, yielding double the amount of tar in comparison to other Indian coals. Mining of these coals generates a large volume of waste materials. These coals generally contain $2 \%-8 \%$ total sulfur, where $75 \%-90 \%$ is of organic sulfur, while the rest is in inorganic form viz. sulfate and pyritic sulfur (Baruah and Khare 2007a). Ledo and Baragolai coal of Makum coalfield, Assam, India contains $28.2 \%$ and $21.5 \%$ of inorganic and $71.7 \%$ and $78.5 \%$ of organic sulfur, respectively (Baruah et al. 2006). In a study, proximate and ultimate analysis of coal collected from Makum coalfield, Assam showed $3.31 \%, 2.95 \%$ and $2.16 \%$ of ash content, total sulfur and organic sulfur, respectively (Saikia et al. 2014a). The volatile matter and vitrinite content of the Makum coalfield, Assam were $42.3 \%$ and around $93 \%$, respectively (Saikia et al. 2014a). Total sulfur of Namchik coalfield, Arunachal Pradesh ranged $1.23 \%-4.84 \%$, with organic sulfur constituting $\sim 41 \%-74 \%$ of total sulfur and volatile matter ranged $41.8 \%-46.6 \%$ (Chandra et al. 1984). Similarly, in Bapung coals of Jaintia Hills, Meghalaya, organic sulfur was more abundant among the different sulfur species constituting an average $62 \%$ of organic sulfur of the total sulfur content of $4.59 \%$ in it (Ahmed and Rahim 1996). Total sulfur sometimes exceeding $7 \mathrm{wt} \%$ out of which the organic sulfur content accounts for about $75 \%$ and the rest is inorganic sulfur. Tiru valley coals of Nagaland, India are sub-bituminous to bituminous-D in rank characterized by low to medium moisture (4\%-7\%), moderately high volatile matter content (22\% and $42 \%)$ and high sulfur (5\%-11\%) content (Singh et al. 2012a, b). Ash, volatile matter and total sulfur content of Northern Mongchen and Moulong Kimong coalfields, Nagaland, India ranged $2.01 \%-19.5 \%, 34.9 \%-44.8 \%$ and $3.23 \%-5.21 \%$, respectively (Das et al. 2015).

In addition to high sulfur and volatile matter, and low ash content of northeast coal, many environmental sensitive organic and mineral bound elements remain enriched in these coals that can cause air, water and land pollution. Sub-bituminous coals of Assam obtained from Makum coalfield showed that $\mathrm{Fe}, \mathrm{Co}, \mathrm{Ni}, \mathrm{Cu}$ and $\mathrm{Zn}$ are significantly mineral bound, $\mathrm{Mg}, \mathrm{Ca}$ and $\mathrm{Mn}$ are organic bound, while $\mathrm{Cd}$ is $50 \%$ bound to either organic or mineral matter (Baruah et al. 2003). The aqueous leaching of these coals 
showed their tendency to atmospheric weathering and highly acidic water formed during the leaching process enhanced the mobilization of associated trace and heavy metals ( $\mathrm{Fe}, \mathrm{Mg}, \mathrm{Bi}, \mathrm{Al}, \mathrm{V}, \mathrm{Cu}, \mathrm{Cd}, \mathrm{Ni}, \mathrm{Pb}$, and $\mathrm{Mn}$ ) above the regulatory levels (Baruah et al. 2006). Element concentrations such as $\mathrm{Cr}, \mathrm{Mn}, \mathrm{Ni}, \mathrm{Cu}, \mathrm{Zn}, \mathrm{As}$ and $\mathrm{Pb}$ in coals obtained from Makum coalfield, Assam were 5, 23, 5, 2, 27,1 and $4 \mathrm{mg} / \mathrm{kg}$, respectively. Concentrations of these elements in coals from Moulong Kimong coalfield, Nagaland were 4, 2289, 3, 2, 49, 2 and $1 \mathrm{mg} / \mathrm{kg}$, respectively (Saikia et al. 2014a). Study further indicated that many of these elements were associated with hematite, magnetite, and goethite in the coals.

\section{Environmental issues associated with coal mining and its utilization in the region}

Unscientific mining of minerals poses a serious threat to the environment, resulting in reduction of forest cover and loss of biodiversity, soil erosion and pollution of air, water and land. The primitive and unscientific 'rat-hole' method of mining adopted by private operators and related activities have caused large-scale environmental degradation and severe ecosystem destruction in Meghalaya (Swer and Singh 2003, 2004; Sarma 2005a, b). Large scale denudation of forest cover, scarcity of water, air and water pollution, degradation of soil and agricultural lands, land subsidence, haphazard dumping of coal and overburden are some of the conspicuous environmental implications of coal mining in north eastern coal mines of Meghalaya, India (Swer and Singh 2004). Based on a study in the Nokrek Biosphere Reserve in Meghalaya, India, it is revealed that coal mining has adversely affected the vegetation and the density of trees, shrubs and herbs in mined areas (Sarma and Barik 2011).

The mining and cleaning of coal at local processing sites creates large quantities of ambient particulate matter (Ghose and Banerjee 1995; Ghose and Majee 2000). Opencast mining operations contribute major air pollutants to the atmosphere and are responsible for environmental degradation by deteriorating the air quality in respect to dust, fine coal particles and other gaseous pollutants (Mukhopadhyay et al. 2010). The major sources of air pollution in coal mining area include: drilling and blasting, loading and unloading of coal and overburden, movements of heavy vehicles on haul roads, dragline operations, crushing of coal in feeder breakers, presence of fire, exposed pit faces, wind erosion and exhaust of heavy earthmover machinery (Nair and Sinha 1987; Ghose and Majee 2007; Huertas et al. 2011). According to Ghose and Banerjee (1997), air pollution caused by washeries is more acute than any other coal processing operations.
Based on a report on ambient air quality around northeastern coalmines in Margherita, Assam, the maximum daily average values of SPM (Suspended Particulate Matter), RPM (Respirable Particulate Matter), $\mathrm{SO}_{2}$ and $\mathrm{NO}_{x}$ were found to be $214,60,25$ and $52 \mu \mathrm{g} / \mathrm{m}^{3}$, respectively (Envirocon 2010). Except for SPM, all other values were within CPCB guidelines (CPCB 2009). Atmospheric concentration of gaseous $\mathrm{NH}_{3}, \mathrm{SO}_{2}$ and $\mathrm{NO}_{2}$ released from the mining activities in open cast mine area of Tirap colliery, Margherita (Assam), ranged between 4.7-40.03, 1.47-6.14, and $1.92-2.40 \mu \mathrm{g} / \mathrm{m}^{3}$, respectively, and particulate $\mathrm{NH}_{4}{ }^{+}$ in $\mathrm{PM}_{10}$ and $\mathrm{PM}_{2.5}$ ranged between $0.02-0.07$ and $0.008-0.03 \mu \mathrm{g} / \mathrm{m}^{3}$, respectively (Sarmah et al. 2012). The study further suggested that low emission and deposition of $\mathrm{NO}_{x}$ and $\mathrm{SO}_{x}$ prevents the greater formation of acidic species due to neutralization with $\mathrm{NH}_{4}{ }^{+}$. Source apportionment of $\mathrm{PM}_{2.5}$ levels at the suburban site of northeast India (Khare and Baruah 2010) showed that largest contribution to aerosol mass in $\mathrm{PM}_{2.5}$ is from crustal sources (38\%) followed by coal combustion ( $26 \%$ ), industrial and vehicular emissions (19\%), wood burning (9\%) and secondary aerosol formation (8\%). Among different elements, emissons of Te, $\mathrm{Fe}, \mathrm{Mn}, \mathrm{Cd}, \mathrm{Sn}$ and $\mathrm{Sb}$ were related to coal burning (Khare and Baruah 2010).

Coke industry is one of the major coal utilization industries in northeast India. To assess the impact of coke oven burning high sulfur and volatile matter containing coal on ambient air quality, levels of $\mathrm{SO}_{2}, \mathrm{PM}_{2.5}$ and trace metals were investigated (Khare and Baruah 2011). The study showed that total emissions of $\mathrm{PM}_{2.5}$, total carbon (TC), black carbon (BC) and organic carbon (OC) ranged between 72-306, 49-217, 0.71-2.9 and 48-214 t/year, respectively and the concentration of trace metals was in the decreasing order as: $\mathrm{Te}>\mathrm{Mn} \sim \mathrm{V}>\mathrm{Cr}>\mathrm{Co}>$ $\mathrm{Mo}>\mathrm{Cu}>\mathrm{Zn} \sim \mathrm{Sb}>\mathrm{Sn}>\mathrm{Cd} \sim \mathrm{Ni}>\mathrm{As}>\mathrm{Se}>\mathrm{Hg}$. The study further indicated that emission rates of metals were dependent on the volatility of the metals, condition of coke ovens and rank of coal (Khare and Baruah 2011).

In addition to air pollution, problems of AMD (Acid Mine Drainage) are intensely localized in the coalfields of northeast India, where ecology of the surrounding area is badly disrupted. The rejects and coals dumped near the pit entrance are exposed to the environment. Being highly enriched with sulfur, pyrite present in these materials is oxidized and hydrolysed and therefore is well known for the generation of AMD (Tiwary 2001; Baruah et al. 2005, 2006; Baruah 2009; Baruah and Khare 2007a). Metals concentrations in mine water in India and the world is shown in Table 2. As it is visible, metals such as $\mathrm{Fe}, \mathrm{Cu}$, $\mathrm{Mn}, \mathrm{Zn}, \mathrm{Ni}$ and $\mathrm{Pb}$ in mine water of northeast India (Jaintia and Makum) showed higher concentrations as compared to other mining sites in India. $\mathrm{Zn}$ and $\mathrm{Pb}$ showed the 
Table 2 Metal contents in mine water $(\mu \mathrm{g} / \mathrm{L})$ in few coal mines in northeast India, India and the world

\begin{tabular}{lrlllllllll}
\hline Parameter & $\mathrm{Fe}$ & $\mathrm{Cu}$ & $\mathrm{Mn}$ & $\mathrm{As}$ & $\mathrm{Zn}$ & $\mathrm{Ni}$ & $\mathrm{Pb}$ & $\mathrm{Cr}$ & $\mathrm{Cd}$ & $\mathrm{References}$ \\
\hline Jaintia coalfield (Meghalaya, India) & 118,400 & 320 & 4070 & - & 4220 & 1080 & 430 & 60 & 30 & Sahoo et al. (2012) \\
Jharia coalfield (Jharkhand, India) & 423 & 32.3 & 136 & 3.4 & 106.1 & 17.6 & 14.9 & 8.1 & Singh et al. (2009) \\
Raniganj (West Bengal, India) & 329 & 18.8 & 39.4 & 10.06 & 60 & 45.6 & 22.6 & 44.6 & Singh et al. (2009) \\
West Bokaro coalfields (Jharkhand, India) & 652 & 46 & 1431 & 7.21 & 194 & 154 & 34.3 & 81.2 & Singh et al. (2009) \\
Makum (Assam, India) & 105,300 & 310 & 10,200 & & 1530 & 3120 & 270 & 56 & 35 & Equeenuddin et al. (2010) \\
Karnen (Iran) & 192,500 & 350 & 30,900 & & 2070 & 1060 & 180 & 850 & 18 & Shahabpour et al. (2005) \\
Dogye coalmine (Korea) & 176,300 & 430 & 8360 & & 2120 & & & & Chon and Hwang (2000) \\
\hline
\end{tabular}

maximum concentrations in Jaintia coalfield of Meghalaya, northeast India and $\mathrm{Ni}$ showed the maximum level in Makum coalfield of Assam. Such high concentrations of metals in these sites can be attributed to higher leaching under acidic conditions in these coalfields. However, elemental contents in leachate water are controlled by three factors: the oxidation rate of pyrite, the acidity of the leachate water and the mineralogy of the rejects (Baruah and Khare 2010). Further, it depends on the element content in the coal. Concentration of toxic elements present in northeastern and other coals in India is shown in Table 3. Toxic metal such as $\mathrm{Cd}$ showed the maximum level in Jaintia coal of Meghalaya, northeast India. In a study on elemental leaching of Meghalaya coals, elements such as $\mathrm{Al}, \mathrm{P}, \mathrm{S}, \mathrm{K}, \mathrm{Ti}, \mathrm{Cr}, \mathrm{Co}, \mathrm{Zn}$ showed negative correlations with $\mathrm{pH}$ (Baruah and Khare 2010). The release of Al, Si, P, $\mathrm{Cl}, \mathrm{K}, \mathrm{Ti}, \mathrm{Mn}, \mathrm{Co}$ and $\mathrm{Ni}$ concentrations in the leachates depends on pyrite oxidation and dissolution (Yue and Zhao 2008), whereas Cd, Sn, Sb and Te contents in the leachates are mainly controlled by adsorption on Fe hydroxides, which is indirectly influenced by $\mathrm{pH}$. The concentrations of trace and potentially harmful elements ( $\mathrm{Sb}, \mathrm{As}, \mathrm{Cd}, \mathrm{Cr}, \mathrm{Co}$, $\mathrm{Cu}, \mathrm{Pb}, \mathrm{Mn}, \mathrm{Ni}, \mathrm{V}$, and $\mathrm{Zn}$ ) in the Meghalaya coals mine rejects ranged (mg/kg): 11.1-12.6, 1.3-25.9, 5-5.1,
259-361, 20.9-22, 23.6-32.9, 98-149, 87-104, 36.4-58, 50-55 and 35.8-55, respectively, and among these $\mathrm{Sb}$ and Cd showed high enrichment factor showing build up in the environment (Baruah and Khare 2010).

Impact of AMD in the streams and groundwater at the vicinity of collieries is a growing problem in northeast India. The Meghalaya State Pollution Control Board, Shillong (MSPCB 2007) reported a case of massive fish death in Lukha River on the eastern border of Jaintia Hills district, which was attributed to AMD contaminating the stream water and sediments. Swer and Singh (2003, 2004) have reported the lack of commonly found aquatic life forms such as fish, frogs and benthic macroinvertibrate such as Plecoptera, Ephemeroptera and Tricoptera in water bodies of coal mining areas in Jaintia Hills, Meghalaya. Overall, socio-economic and ecological impacts in the area includes: severe scarcity of freshwater resources for domestic use and drinking purposes by the local community causing breach of basic human right; lack of aquatic life in many rivers and streams and reduced vegetation diversity; decreased agricultural productivity etc. (Swer and Singh 2004). Swer and Singh (2004) further reported that water quality in the Jaintia Hills of Meghalaya is highly affected as evidenced by low $\mathrm{pH}$ (in the range of

Table 3 Concentration of some toxic elements present in northeast India and other Indian coals/lignite $(\mathrm{mg} / \mathrm{kg})$

\begin{tabular}{|c|c|c|c|c|c|c|c|c|c|}
\hline Parameters & As & $\mathrm{Cu}$ & $\mathrm{Mn}$ & $\mathrm{Zn}$ & $\mathrm{Ni}$ & $\mathrm{Pb}$ & $\mathrm{Cr}$ & $\mathrm{Cd}$ & References \\
\hline $\begin{array}{l}\text { Jaintia coalfield } \\
\text { (Meghalaya, India) }\end{array}$ & $1-3$ & $2.8-40$ & $36.6-81.5$ & $8.5-36.6$ & $2-9.8$ & $2.4-13.7$ & $17.9-55.5$ & 5 & $\begin{array}{l}\text { Baruah and Khare } \\
\text { (2010) }\end{array}$ \\
\hline $\begin{array}{l}\text { Makum coalfield (Assam, } \\
\text { India) }\end{array}$ & $0.04-0.24$ & $9.86-30.35$ & $15.27-63.81$ & - & - & $5.06-24.13$ & - & - & $\begin{array}{l}\text { Mukherjee and } \\
\text { Srivastava (2005) }\end{array}$ \\
\hline $\begin{array}{l}\text { Jammu and Kashmir, } \\
\text { India }\end{array}$ & 9.5 & 16.7 & 39 & 17.3 & 42.5 & 13.5 & 31.5 & 1.8 & Banerjee et al. (2000) \\
\hline $\begin{array}{l}\text { Damodar Koel Valley } \\
\text { coal }\end{array}$ & 8.2 & 21.4 & 57.7 & 33.3 & 28 & 17.9 & 47.5 & 2.2 & Banerjee et al. (2000) \\
\hline $\begin{array}{l}\text { Wardha Godavari Valley } \\
\text { coal }\end{array}$ & 2.1 & 29.5 & 58.6 & 29.2 & 25 & 4.5 & 54.5 & 2.8 & Banerjee et al. (2000) \\
\hline $\begin{array}{l}\text { Pench Kanhan Tawa } \\
\text { Valley coal }\end{array}$ & 5.8 & 24.3 & 85 & 26 & 22.7 & 10.2 & 33.7 & 2.1 & Banerjee et al. (2000) \\
\hline
\end{tabular}


3-5), high conductivity, high concentration of sulphates, iron and other toxic metals, low dissolved oxygen (DO) and high biological oxygen demand (BOD). Such low $\mathrm{pH}$, low DO, higher sulphate content and turbidity in water of coal mining areas are affecting the aquatic life.

Singh and Sinha (1992) reported variation of $\mathrm{pH}$ in northeastern coalfields, $\mathrm{pH} 2.8-4.1$ in Churcha, $\mathrm{pH} 4.2-5.0$ in West Chirimir, pH 5.2-5.6, pH 5.3-6.0 in Rakhikhol and pH 4.0-4.6 in Gorbi coalfields. Highly acidic mine water with high sulphate (up to $1500 \mathrm{mg} / \mathrm{L}$ ) and $\mathrm{Fe}(40 \mathrm{mg} / \mathrm{L}$ ) were reported in Margherita group of mines in Assam (Rawat and Singh 1982). Bhole (1994) reported pH of 3.9, 3.10 and 4.3 in Ledo, Tirap and Bargolia mines of Assam. Based on a similar study carried out in Makum coalfields in Assam by Equeenuddin et al. (2010), it was found that the mine discharges were highly acidic (up to $\mathrm{pH} 2.3$ ) to alkaline (up to $\mathrm{pH}$ 7.6) in nature with high concentration of $\mathrm{SO}_{4}{ }^{2-}$ and mine water was highly enriched with $\mathrm{Fe}, \mathrm{Al}$, $\mathrm{Mn}, \mathrm{Ni}, \mathrm{Pb}$ and $\mathrm{Cd}$. In addition, ground water close to the collieries and AMD affected creeks were highly contaminated by $\mathrm{Mn}, \mathrm{Fe}$ and $\mathrm{Pb}$ but major rivers were not much impacted by AMD due to their large volume of water. Different physico-chemical parameters of surface and groundwater near coalfields in northeast and other parts of India are shown in Table 4. As can be seen in Table 4, pH of surface water near Jaintia coalfield, Meghalaya, India is highly acidic as compared to surface water in other sites in India. The maximum concentrations of metals detected in groundwater near Makum coalfield, Assam, India was (mg/L): 0.018 for $\mathrm{Cr}, 0.2$ for $\mathrm{Ni}, 0.108$ for $\mathrm{Zn}, 2.18$ for $\mathrm{Mn}$, 3.9 for $\mathrm{Fe}, 1.1$ for $\mathrm{Al}, 0.061$ for $\mathrm{Pb}$, and 0.009 for $\mathrm{Cu}$, in river water, the maximum concentrations were $(\mathrm{mg} / \mathrm{L})$ : 0.06 for Ni, 0.016 for $\mathrm{Zn}, 0.94$ for $\mathrm{Mn}, 2.47$ for $\mathrm{Fe}, 0.42$ for $\mathrm{Al}, 0.017$ for $\mathrm{Cd}, 0.056$ for $\mathrm{Pb}$ and 0.021 for $\mathrm{Cu}$ (Equeenuddin et al. 2010). In a study by Abhishek et al. (2006), water quality parameters in groundwater in Jharia coalfield ranged: $\mathrm{pH}(6.72-7.94)$, TDS $(213-530 \mathrm{mg} / \mathrm{L})$, $\mathrm{SO}_{4}{ }^{2-}(8.8-41.2 \mathrm{mg} / \mathrm{L}), \quad \mathrm{Cl}^{-} \quad(19.8-96 \mathrm{mg} / \mathrm{L}), \quad \mathrm{NO}_{3}{ }^{-}$ (3-77.7 mg/L), Fe (0.13-2.18 mg/L), Zn (0.02-0.04 mg/L), $\mathrm{Pb}(0.01-0.04 \mathrm{mg} / \mathrm{L})$. The maximum TDS, $\mathrm{NO}_{3}{ }^{-}$and $\mathrm{Fe}$ concentrations exceeded the Bureau of Indian Standards (BIS) limit for drinking water quality. In surface water, water quality parameters varied between (Abhishek et al. 2006): pH (7.15-7.76), EC (250.6-470.6 $\mu \mathrm{S} / \mathrm{cm})$, TDS (237-616 mg/L), DO (2.5-5.8 mg/L), BOD (3.8-13.7 mg/L), $\mathrm{Pb} \quad(0.01-0.03 \mathrm{mg} / \mathrm{L}), \quad \mathrm{Zn} \quad(0.03-0.09 \mathrm{mg} / \mathrm{L})$ and $\mathrm{Fe}$ (0.15-1.91).

Metals concentrations in stream sediments around Makum coal field of Assam ranged $(\mathrm{mg} / \mathrm{kg})$ : 5.5-71.7, 100-386, 3.1-21.1, 0.48-2.1, 23.1-231, 101-9163 and 17.8-264 for $\mathrm{Cu}, \mathrm{Cr}, \mathrm{Pb}, \mathrm{Cd}, \mathrm{Zn}, \mathrm{Mn}$ and $\mathrm{Ni}$, respectively (Equeenuddin et al. 2013). The study further indicated that higher concentrations of all metals were available in exchangeable fraction under strongly acidic environment. Based on their mobility and potential bioavailability, metals were in the order of $\mathrm{Cd}>\mathrm{Pb}>\mathrm{Mn}>\mathrm{Ni} \geq$ $\mathrm{Zn}>\mathrm{Cu}>\mathrm{Cr}$.

\section{Management and treatment strategies to reduce environmental impacts of coals}

Since coal mining and its utilization in coal based industries is associated with environmental issues, it is necessary to manage or mitigate its impact on environment or clean coal prior to its utilization. An attempt was made by Dowarah et al. (2009) to achieve eco-restoration of a highsulfur containing coal mine overburden dumping site through primary and secondary ecological succession of native plant species in Tirap Collieries, Assam, India. The study revealed that planting of herbaceous monocots with fibrous root systems such as citronella, lemon grass, Saccharum spontaneum, lianes and shrub species accelerates the ecological processes in an adverse mine overburden environment of Tirap colliery and a secondary sere ecological succession was observed in the restored mine site. In addition, $80 \%-100 \%$ vegetation coverage was observed, the plant species density was more than $80 \%$, and soil organic matter increased from $0.001 \%-0.005 \%$ to $0.5 \%-1.3 \%$. Restoration refers to reinstatement of the pre-mining ecosystem in all its structural and functional aspects (Bradshaw 2000). Re-vegetation plays a crucial role in enhancing the soil fertility status in mine spoil and in the stabilization of dump slopes by creating mechanical reinforcement of dump material and enhancing shear strength of dump material (Singh 2011; Singh et al. 2012a, b). Soil structure development, nutrient cycling, and soil chemical and physical limitations to plant growth are mediated and mitigated by microorganisms and they play a very important role in eco-restoration (Singh and Singh 2006).

Mineral matter and sulfur exhibit harmful effects on utilization of coal. De-sulfurization and de-ashing are essential for sustainable utilization of low rank high sulfur coals used in different industries (Baruah et al. 2006; Baruah and Khare 2007b; Saikia et al. 2013). Sequential solvent extraction was found to be an effective method of desulfurization of high sulfur containing Assam coal, especially for organic sulfur, which could be removed up to $89 \%$ (Das and Sharma 2001). Investigation on desulfurization of coal samples from Boragolai and Ledo collieries of Makum coal field, Assam, India using alkali treatment leads to over $70 \%$ removal of inorganic sulfur, and removal of sulfur increased with increase in alkali concentration and treatment time (Mukherjee and Borthakur 2003). In another study, for the same coal, solvent 


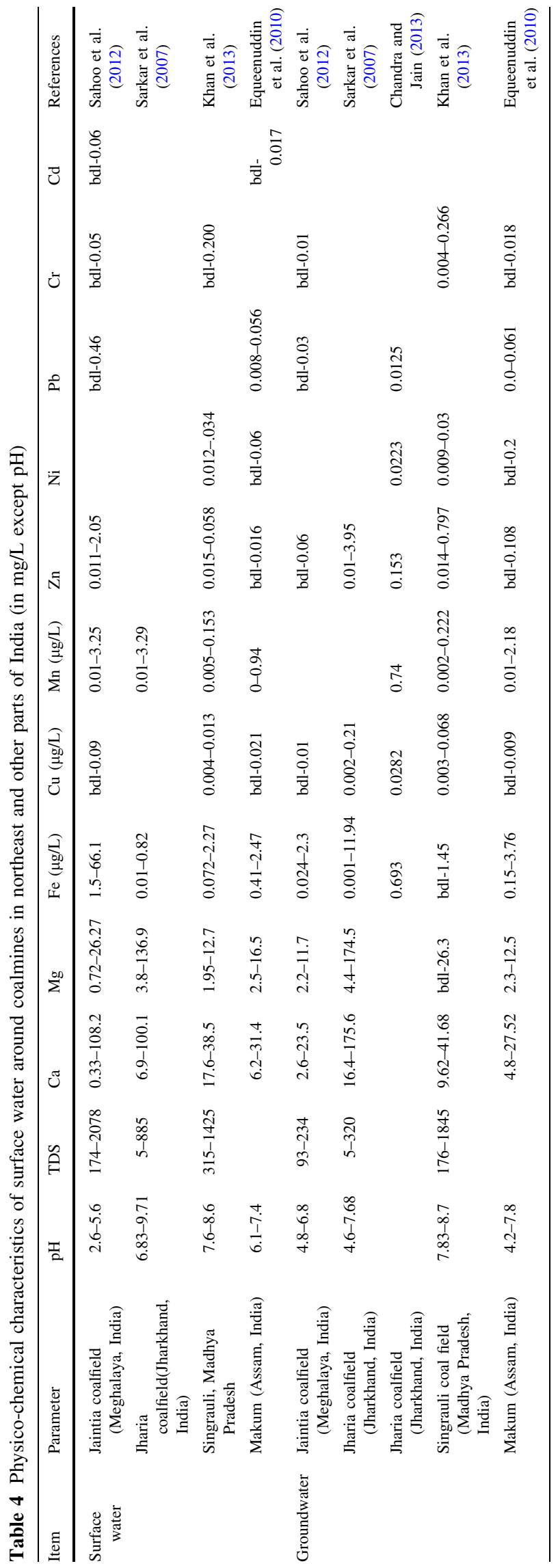

extraction and alkali treatment showed successful removal of organic and inorganic sulfur. Solvent extraction using dimethyl formamide (DMF) increased desulfurization of the oxidized Baragolai and Ledo coals up to $95 \%$ and $93 \%$ for inorganic sulfur and $31 \%$ and $23 \%$ organic sulfur, respectively, while the alkali treatment showed complete removal of inorganic sulfur and a maximum of $33 \%$ and $26.4 \%$ organic sulfur for these coals, respectively (Baruah and Khare 2007b). Alkali treatment of high sulfur Assam coal using mixtures (1:1) of $16 \%$ sodium hydroxide and potassium hydroxide solution followed by $10 \%$ hydrochloric acid could remove $50 \%-54 \%$ of the ash, total inorganic sulfur, and around $25 \%$ organic sulfur (Mukherjee 2003). $9.4 \%$ of the total organic sulfur was removed by electron transfer process (Borah and Baruah 1999). In another study, approximately $93 \%$ and $98 \%$ of the pyritic sulfur was removed in the case of the Baragolai and Ledo coal of Makum, Assam, respectively, using $15 \%$ (v/v) hydrogen peroxide $+0.1 \mathrm{~N}$ sulfuric acid (Mukherjee and Srivastava 2004). An attempt was made to clean some low rank medium to high sulfur coal samples from northeast India using low ultrasonic energy $(20 \mathrm{kHz})$ in the presence of $\mathrm{H}_{2} \mathrm{O}_{2}$ solutions and it showed removal of $31 \%, 48 \%, 51 \%, 48 \%$ and $32 \%$ of total sulfur, organic sulfur, pyritic, sulfate sulfur and ash, respectively (Saikia et al. 2014b). In a similar study, treatment using application of ultrasonic energy $(20 \mathrm{kHz})$ in aqueous and mixed alkali media $(1: 1 \mathrm{KOH}$ and $\mathrm{NaOH})$ on coals collected from Assam and Nagaland, India showed that the maximum removal of ash, pyritic sulfur, sulphate sulfur and total sulfur were $87.52 \%, 83.92 \%, 12.50 \%$ and $18.80 \%$, respectively (Saikia et al. 2014c). Ultrasound assisted coal de-sulfurization and de-ashing is partially green approach that has been recently studied by other researchers (Hoffmann et al. 1996; Ze et al. 2007; Wang and Yang, 2007; Mello et al. 2009; Shen et al. 2012).

In addition to several physico-chemical desulfurization methods, biodesulfurization using Thiobacillus ferrooxidans (ATCC 13984) was attempted for Assam coal (Dastidar et al. 2000). Results showed that the rate of pyritic sulfur removal was retarded at higher concentrations of ferrous and ferric ions that need to be controlled to maintain high rate of removal (Dastidar et al. 2000). In general, AMD can be remediated by two generic approaches i.e. active or passive treatment (Skousen et al. 1998; Wolkersdorfer 2008). Active treatment requires the use of alkaline materials (lime, limestone, hydrated lime, caustic soda, soda ash, etc.) or aeration to reduce acidity and precipitate metals, while passive (abiotic and biological) treatment allows chemical and biological processes to take place naturally in a controlled environment (Costello 2003; Johnson and Hallberg 2005; Sheoran and Sheoran 2006; Rios et al. 2008; Sheoran et al. 2010). A pilot plant 
Table 5 Pollution standards for air quality in India

\begin{tabular}{lllll}
\hline Pollutant & Time-weighted averages & \multicolumn{2}{l}{ Concentration in ambient air (mg/L) } \\
\cline { 3 - 5 } & & $\begin{array}{l}\text { New coal mines (after } \\
\text { December 1998) }\end{array}$ & $\begin{array}{l}\text { Existing coalfields/ } \\
\text { mines }\end{array}$ & $\begin{array}{l}\text { Old coal mines (Jharia, } \\
\text { Raniganj, Bokaro) }\end{array}$ \\
\hline SPM & Annual average & 360 & 430 & 500 \\
& $24 \mathrm{~h}$ & 500 & 600 & 700 \\
$\mathrm{RPM}$ & Annual average & 180 & 215 & 250 \\
$\mathrm{SO}_{2}$ & $24 \mathrm{~h}$ & 250 & 300 & 300 \\
& Annual average & 80 & 80 & 80 \\
$\mathrm{NO}_{x}$ & $24 \mathrm{~h}$ & 120 & 120 & 120 \\
& Annual average & 80 & 80 & 80 \\
\end{tabular}

consisting of sequential alkalinity producing (SAP) system coupled with biological processes was designed for treatment of AMD from coalmines of Meghalaya, northeast India (Baruah et al. 2010). The treatment system was found to be effective in reducing TDS, conductivity, sulphate and toxic elements.

In India, the Ministry of Environment and Forests (MoEF) plays a key role in regulating the environmental impacts of mining and in providing clearances for mining in forest lands. Some environmental protection measures include: prevention of pollution at source; ensuring polluters pay principle; protection of heavily polluted areas and river stretches; encouragement of development and application of best available technological solutions; and involving the public in decision making (Mehta 2002). Under Mineral Concession Rules, 1960, it is required to specify the area indicating impact of mining activity on forest, land and environment, scheme for restoration of the area by afforestation, adoption of pollution control devices. According to Article 23 of the Mineral Conservation and Development Rules (1988), conditions for the abandonment of any mine need to be laid down by the mining company and provision of a plan for dealing with the environment, and is liable to protect and control pollution during the mining and post mining operations. The law further lays guidelines to restore or protect the flora of the area under the mining lease and nearby areas, technically, economically and environmentally.

The main environmental acts that impact the mining industry in India are: The Wildlife (Protection) Act, 1972 (amended in 1991); The Water (Prevention and Control of Pollution) Act, 1974 (amended in 1988); The Forest (Conservation) Act, 1980 (amended in 1988); The Air (Prevention and Control of Pollution) Act, 1981 (amended in 1988); and The Environment (Protection) Act, 1986 (with rules 1986 and 1987). Separate pollution standards for air quality and coal mine effluents has been laid down
Table 6 Pollution standards for coal mine effluents

\begin{tabular}{ll}
\hline Parameter & Level \\
\hline $\mathrm{pH}$ & $5.5-9.0$ \\
TSS (mg/L) & 100 \\
Oil and grease (mg/L) & 10 \\
COD (mg/L) & 250 \\
BOD (mg/L) & 30 \\
Phenolics (mg/L) & 1.0 \\
\hline
\end{tabular}

by Central Pollution Control Boards for coal mining in India (Tables 5, 6).

In order to achieve sustainable utilization of coal resources integrated approach considering various aspects to reduce its environmental impacts is necessary. Proper implementation of regulatory rules and policies is as important as other management strategies to deal with environmental issues.

\section{Conclusions}

Demand for coal in India is projected to increase dramatically in short to medium term. This would result in increased coal mining in different parts of India including northeast region. Since, coals in northeast India is characterised by high sulfur and volatile matter contents that exhibits more potential harmful impacts, extra efforts are required to manage these coals to reduce its environmental impacts in the region. More studies need to be done in the field to assess the impact of coal mining on biodiversity, soil, air, surface and ground water in northeast India. Although several researches on desulfurization, de-ashing and demineralization techniques have been made, effort should be made to do further research on developing effective, low cost and environmental friendly technologies 
to clean coal and to use these techniques in the field. Further, it is essential to encourage and emphasize on alternative clean sources of energy to meet future energy demands.

Open Access This article is distributed under the terms of the Creative Commons Attribution 4.0 International License (http://crea tivecommons.org/licenses/by/4.0/), which permits unrestricted use, distribution, and reproduction in any medium, provided you give appropriate credit to the original author(s) and the source, provide a link to the Creative Commons license, and indicate if changes were made.

\section{References}

Abhishek R, Tiwary K, Sinha SK (2006) Status of surface and groundwater quality in coal mining and industrial areas of Jharia coalfield. Ind J Environ Prot 26:905-910

Ahmed M, Rahim A (1996) Abundance of sulfur in Eocene coal beds from Bapung, Northeast India. Int J Coal Geolgy 30:315-318

Banerjee NN, Ghosh B, Das A (2000) Trace metals in Indian Coals; CFRI golden jubilee monograph. Allied Publishers Ltd, New Delhi, p 13

Baruah BP (2009) Environmental studies around makum coalfields. LAP Lambert Academic Publishing, India

Baruah BP, Khare P (2007a) Pyrolysis of high sulfur Indian coals. Energy Fuels 21:3346-3352

Baruah BP, Khare P (2007b) Desulfurization of oxidized Indian coals with solvent extraction and alkali treatment. Energy Fuels 21:2156-2164

Baruah BP, Khare P (2010) Mobility of trace and potentially harmful elements in the environment from high sulfur Indian coal mines. Appl Geochem 25:1621-1631

Baruah MK, Kotoky P, Borah GC (2003) Distribution and nature of organic/mineral bound elements in Assam coals, India. Fuel 82:1783-1791

Baruah BP, Kotoky P, Rao PG (2005) Genesis of acid mine drainage from coalfields of Assam, India. In: Proceedings of international seminar on coal science and technology-emerging global dimensions: global coal. Allied Publishers. ISBN:81-7764-818-7

Baruah BP, Saikia BK, Kotoky P, Rao PG (2006) Aqueous leaching of high sulfur sub-bituminous coals in Assam, India. Energy Fuels 20:1550-1555

Baruah BP, Khare P, Rao PG (2010) Management of acid mine drainage (AMD) in Indian coal mines In: Proceedings of international seminar on mineral processing technology (MPT2010), pp 1163-1170

Bhole AG (1994) Acid mine drainage and its treatment. Proceedings of International Symposium on the impact of mining on the envirnment. Paithankar et al. (ed) Oxford \& IBH Pub., Nagpur, Jan 11-16, pp 131-141

Borah D, Baruah MK (1999) Electron transfer process 1. Removal of organic sulphur from high sulphur Indian coal. Fuel 78:1083-1088

Bradshaw AD (2000) The use of natural processes in reclamationadvantages and difficulties. Landsc Urban Plan 51:89-100

Centre for Science and Environment, CSE (2012) Coal mining, pp 1-5. http://www.cseindia.org/userfiles/fsheet2.pdf. Accessed 5 Apr 2015

Chandra A, Jain MK (2013) Evaluation of heavy metals contamination due to overburden leachate in groundwater of coal mining area. J Chem Biol Phys Sci 3:2317-2322
Chandra D, Mazumdar K, Basumallick S (1983) Distribution of sulfur in the tertiary coals of Meghalaya, India. Int J Coal Geol 3:63-75

Chandra D, Ghose S, Chaudhuri SG (1984) Abnormalities in the chemical properties of tertiary coals of Upper Assam and Arunachal Pradesh. Fuel 63:1318-1323

Chaulya SK, Chakraborty MK (1995) Perspective of new national mineral policy and environmental control for mineral sector. In: Proceedings of national seminar on status of mineral exploitation in India, New Delhi, India, pp 114-123

Chon HT, Hwang JH (2000) Geochemical characteristics of the acid mine drainage in the water system in the vicinity of the Dogye coalmine in Korea. Environ Geochem Health 22:155-172

Chou CL (2012) Sulfur in coals: a review of geochemistry and origins. Int J Coal Geol 100:1-13

Costello C (2003) Acid mine drainage: innovative treatment technologies. US Environmental Protection Agency, Office of Solid Waste and Emergency Response. Technology Innovation Office, Washington, DC. http://www.cluin.org/download/studentpapers/ costello_amd.pdf

CPCB (Central Pollution Control Board) (2009) National Ambient Air Quality Standards (NAAQS), under Gazette Notification B-29016/20/90/PCI-1, New Delhi

Das A, Sharma DK (2001) Organic desulfurization of assam coal and its sulfur-rich lithotypes by sequential solvent extraction to obtain cleaner fuel. Energy Source 23:687-697

Das T, Saikia BK, Baruah BP, Das D (2015) Characterizations of humic acid isolated from coals of two Nagaland coalfields of India in relation to their origin. J Geol Soc India $86: 468-474$

Dastidar MG, Malik A, Roychoudhury PK (2000) Biodesulfurization of Indian (Assam) coal using Thiobacillus ferrooxidans (ATCC 13984). Energy Conver Manag 41:375-388

Dowarah J, DekaBoruah HP, Gogoi J, Pathak N, Saikia N, Handique AK (2009) Eco-restoration of a high-sulphur coal mine overburden dumping site in northeast India: a case study. J Earth Syst Sci 118:597-608

Envirocon (2010) A report on ambient air quality, water/waste water analysis \& noise level measurement at north eastern coalfields. Coal India Ltd, Margherita, pp 1-20

Equeenuddin SM, Tripathy S, Sahoo PK, Panigrahi MK (2010) Hydrogeochemical characteristics of acid mine drainage and water pollution at Makum Coalfield, India. J Geochem Explor 105:75-82

Equeenuddin SM, Tripathy S, Sahoo PK, Panigrahi MK (2013) Metal behavior in sediment associated with acid mine drainage stream: role of $\mathrm{pH}$. J Geochem Explor 124:230-237

Ghose MK, Banerjee SK (1995) Status of air pollution caused by coal washery projects in India. Environ Monit Assess 38:97-105

Ghose MK, Banerjee SK (1997) Physico-chemical characteristics of air-borne dust emitted by coal washery in India. Energy Environ Monit 13:11-17

Ghose MK, Majee SR (2000) Assessment of dust generation due to opencast coal mining-an Indian case study. Environ Monit Assess 61:257-265

Ghose MK, Majee SR (2007) Characteristics of hazardous airborne dust around an Indian surface coal mining area. Environ Monit Assess 130:17-25

Hoffmann MR, Hua I, Hochemer R (1996) Application of ultrasonic irradiation for the degradation of chemical contaminants in water. Ultrason Sonochem 3:163-172

Huertas J, Camacho D, Huertas M (2011) Standardized emissions inventory methodology for open pit mining areas. Environ Sci Pollut Res 19:2784-2794

Johnson DB, Hallberg KB (2005) Acid mine drainage remediation options: a review. Sci Tot Environ 338:3-14 
Khare P, Baruah BP (2010) Elemental characterization and source identification of $\mathrm{PM}_{2.5}$ using multivariate analysis at the suburban site of North-East India. Atmos Res 98:148-162

Khare P, Baruah BP (2011) Estimation of emissions of $\mathrm{SO}_{2}, \mathrm{PM}_{2.5}$, and metals released from coke ovens using high sulfur coals. Environ Progr Sustain Energy 30:123-129

Khan I, Javed A, Khurshid S (2013) Physico-chemical analysis of surface and groundwater around Singrauli Coal Field, District Singrauli, Madhya Pradesh, India. Environ Earth Sci 68:1849-1861

Mehta PS (2002) The Indian mining sector: effect on the environment and FDI inflows. In: Conference on foreign direct investment and the environment, 7-8 February, Paris, France

Mello PA, Duarte FA, Nunez MAG, Alencar MS, Moreira EM, Korn $M$ et al (2009) Ultrasound-assisted oxidative process for sulfur removal from petroleum product feedstock. Ultrason Sonochem $16: 732-736$

Ministry of Coal (2014) Government of India, provisional coal statistics 2013-14, coal reserves. http://coal.nic.in. Accessed 12 Aug 2015

Mukherjee S (2003) Demineralization and desulfurization of highsulfur Assam coal with alkali treatment. Energy Fuels 17:559-564

Mukherjee S, Borthakur PC (2003) Effects of alkali treatment on ash and sulphur removal from Assam coal. Fuel Process Technol 85:93-101

Mukherjee S, Srivastava SK (2004) Kinetics and energetics of highsulfur northeastern India coal desulfurization using acidic hydrogen peroxide. Energy Fuels 18:1764-1769

Mukherjee S, Srivastava SK (2005) Trace elements in high-sulfur Assam coals from the makum coalfield in the northeastern region of India. Energy Fuels 19:882-891

Mukhopadhyay S, Pal S, Mukherjee AK, Ghosh AR (2010) Ambient air quality in opencast coal mining areas of Bankola area (under Eastern coal field 1td.) of Asansol-Raniganj regions. Ecoscan 4:19-24

Nair PK, Sinha JK (1987) Dust control at deep hole drilling for open peak mines and development of a arrester. J Mines Met Fuel 35(8):360-364

Rajarathnam S, Chandra D, Handique GK (1996) An overview of chemical properties of marine-influenced Oligocene coal from the northeastern part of the Assam-Arakan basin, India. Intern J Coal Geol 29:337-361

Rawat NS, Singh G (1982) The role of micro-organisms in the formation of acid mine drainage in the north eastern coal field of India. Int J Mine Wat 2:29-36

Rios CA, Williams CD, Roberts CL (2008) Removal of heavy metals from acid mine drainage (AMD) using coal fly ash, natural clinker and synthetic zeolites. J Hazard Mater 156:23-35

Sahoo PK, Tripathy S, Equeenuddin SM, Panigrahi MK (2012) Geochemical characteristics of coal mine discharge vis-à-vis behavior of rare earth elements at Jaintia Hills coalfield, northeastern India. J Geochem Explor 112:235-243

Saikia BK, Kakati N, Khound K, Baruah BP (2013) Chemical kinetics of oxidative desulfurization of Indian coals. Int J Oil Gas Coal Tech 6:720-727

Saikia BK, Ward CR, Oliveira MLS, Hower JC, Baruah BP, Braga M, Silva LF (2014a) Geochemistry and nano-mineralogy of two medium-sulfur Northeast Indian coals. Intern J Coal Geol 121:26-34

Saikia BK, Dutta AM, Baruah BP (2014b) Feasibility studies of desulfurization and de-ashing of low grade medium to high sulfur coals by low energy ultrasonication. Fuel 123:12-18

Saikia BK, Dutta AM, Saikia L, Ahmed S, Baruah BP (2014c) Ultrasonic assisted cleaning of high sulphur Indian coals in water and mixed alkali. Fuel Process Technol 123:107-113
Sarkar BC, Mahanta BN, Saikia K, Paul PR, Singh G (2007) Geoenvironmental quality assessment in Jharia coalfield, India using multivariate statistics and GIS. Environ Geol 51:1177-1196

Sarma K (2005a) Impact of coal mining on vegetation: a case study in Jaintia Hills district of Meghalaya, India. M.Sc. diss., International Institute for Geoinformation Science and Earth Observation (ITC), Enschede, the Netherlands

Sarma K (2005b) Impact of Coal Mining on Vegetation: A Case Study in Jaintia Hills District of Meghalaya, India, M.Sc Thesis, International Institute for Geo-information Science and Earth Observation, the Netherlands and Indian Institute of Remote Sensing (IIRS), India

Sarma K, Barik SK (2011) Coal mining impact on vegetation of the Nokrek Biosphere Reserve, Meghalaya, India. Biodiversity 12:154-164

Sarmah M, Khare P, Baruah BP (2012) Gaseous emissions during the coal mining activity and neutralizing capacity of ammonium. Water Air Soil Pollut 223:4795-4800

Shahabpour J, Doorandish M, Abbasnejad A (2005) Mine-drainage water from coal mines of Kerman region, Iran. Environ Geol 47:915-925

Shen Y, Sun T, Liub X, Jiaa J (2012) Rapid desulfurisation of CWS via ultrasonic enhanced metal boron hydrides reduction under ambient conditions. RSC Adv 2:4189-4197

Sheoran AS, Sheoran V (2006) Heavy metal removal mechanism of acid mine drainage in wetlands: a critical review. Miner Eng 19:105-116

Sheoran AS, Sheoran V, Choudhary RP (2010) Bioremediation of acid-rock drainage by sulphate-reducing prokariotes: a review. Miner Eng 23:1073-1100

Singh TN (2011) Assessment of coal mine waste dump behavior using numerical modeling. In: Fuenkajorn K, Phien-wej N (eds) Rock mechanics. Proceedings of the third Thailand symposium. ISBN 9789745336360 , pp 25-36

Singh MP, Singh AK (2000) Petrographic characteristics and depositional conditions of Eocene coals of platform basins, Meghalaya, India. Int J Coal Geol 42:315-356

Singh AN, Singh JS (2006) Experiments on ecological resto-ration of coalmine spoil using native trees in a dry tropical environment, India: a synthesis. New For 31:25-39

Singh G, Sinha DK (1992) The problem of acid mine drainage its occurrence and effects. In: Proceedings of Environment Management of Mining Operations, Department of Environment \& Forest Government of India, pp 156-167

Singh AK, Mondal GC, Tewary BK, Sinha A (2009) Major ion chemistry, solute acquisition processes and quality assessment of mine water in Damodar valley coalfields, India. In: International mine water conference proceedings ISBN Number: 978-0-98026235-3, 19th-23rd October, Pretoria, South Africa, pp 267-276

Singh PK, Singh MP, Singh AK, Naik AS (2012a) Petrographic and geochemical characterization of coals from Tiru valley Nagaland, NE India. Energy Explor Exploit 30:171-192

Singh RS, Tripathi N, Chaulya SK (2012b) Ecological study of revegetated coal mine spoil of an Indian dry tropical ecosystem along an age gradient. Biodegradation 23:837-849

Skousen J, Rose A, Geidel G, Foreman J, Evans R, Hellier W (1998) A handbook of technologies for avoidance and reclamation of acid mine drainage. National Mine Land Reclamation Center, West Virginia University, Morgantown, p 131

Swer S, Singh OP (2003) Coal mining impacting water quality and aquatic biodiversity inJ aintia Hills District of Meghalaya. ENVIS Bull Himal Ecol 11:26-33

Swer S, Singh OP (2004) Status of water quality in coal mining areas of Meghalaya, India. In: National seminar on environmental engineering with special emphasis on mining environment. NSEEME, 19-20 March, Dhanbad, India. pp 26-33 
Tiwary RK (2001) Environmental impact of coal mining on water regime and its management. Water Air Soil Pollut 132:185-199

Wang Y, Yang RT (2007) Desulfurization of liquid fuels by adsorption on carbon-based sorbents and ultrasound-assisted sorbent regeneration. Langmuir 23:3825-3831

Ward CR, Li Z, Gurba LW (2007) Variations in elemental composition of macerals with vitrinite reflectance and organic sulphur in the Greta coal measures, New South Wales, Australia. Intern J Coal Geol 69:205-219

Widodo S, Oschmann W, Bechtel A, Sachsenhofer RF, Anggayana K, Puettmann W (2010) Distribution of sulfur and pyrite in coal seams from Kutai basin (east Kalimantan, Indonesia): implications for paleoenvironmental conditions. Intern $\mathrm{J}$ Coal Geol $81: 151-162$
Wolkersdorfer Ch (2008) Water management at abandoned flooded underground mines. Fundamentals, tracer tests, modelling, water treatment. Springer, New York, pp 235-275

Yue M, Zhao F (2008) Leaching experiments to study the release of trace elements from mineral separates from Chinese coals. Int $\mathrm{J}$ Coal Geol 73:43-51

Zamuda CD, Sharpe MA (2007) A case for enhanced use of clean coal in India: an essential step towards energy security and environmental protection. In: Workshop on Coal Beneficiation and Utilization of Rejects. Ranchi, India

Ze KW, Xin XH, Tao CJ (2007) Study of enhanced fine coal desulfurization and de-ashing by ultrasonic floatation. J Chin Univ Min Technol 17:358-362 